\title{
Effect of alginite on some antioxidant indexes in extracts of two variants of Mentha and their toxicity
}

\author{
Jarmila Eftimová*, Vladimír Petrovič, Vladimír Vodhanel \\ University of Veterinary Medicine and Pharmacy in Kosice, Department of Pharmaceutical Technology, \\ Pharmacognosy and Botany, Slovakia
}

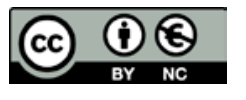

Article Details:

Received: 2021-08-22

Accepted: 2021-10-20

Available online: 2021-11-30

DOI: https://doi.org/10.15414/ainhlq.2021.0030

\begin{abstract}
The experimental work aimed to determine the effect of different applications of alginite on some antioxidant indexes in the extracts of the Mentha $\times$ piperita L. (cultivars Strawberry Mint and Chocolate Mint), and the acute toxicity of water extracts of the studied mint plants to freshwater invertebrates of the genus Daphnia sp. The content of total polyphenols, phenolic acids, and antioxidant activity were determined by spectrophotometric methods. The OECD manual No. 202 was used for the determination of $\mathrm{EC}_{50} 48 \mathrm{~h}$ in the water extracts of both variants of mint. The content of total polyphenols in all groups of the cv. Chocolate Mint ranged from 3.05 to $3.37 \mathrm{mg} \mathrm{CAE} / 100 \mathrm{~g} \mathrm{DW}$. On the other hand, the significantly lower ( $\mathrm{p}<0.001$ ) content of total polyphenols (from 1.01 to $1.38 \mathrm{mg}$ CAE/100 g DW) was found in all groups with the cv. Strawberry Mint. The antioxidant activity determined by the DPPH method was from 115.7 to $119.5 \mathrm{mg}$ TAEC/100 g DW in the cv. Chocolate Mint, but was 2 times lower (from 48.8 to $65.7 \mathrm{mg}$ TAEC/100 g DW) in the cv. Strawberry Mint. The content of phenolic acids in the cv. Chocolate Mint was significantly higher (but only 1.1-fold), than in the cv. Strawberry Mint. The mean acute toxicity after $48 \mathrm{~h}$ exposure of the cv. Chocolate Mint to daphnids was nearly 40 times higher than the mean acute toxicity of the cv. Strawberry Mint $\left(\mathrm{EC}_{50} 0.25 \mathrm{mg} / \mathrm{L} \mathrm{vs}\right.$. $\mathrm{EC}_{50} 9.62 \mathrm{mg} / \mathrm{L}$, respectively). We can conclude, that the cv. Chocolate Mint is a more potent source of substances with antioxidant properties, such as polyphenols and phenolic acids, which is reflected in the significantly increased DPPH radical scavenging activity as compared to the cv. Strawberry Mint. We can only speculate that the higher amounts of the aforementioned active substances in the cv. Chocolate Mint were associated with an increased level of acute toxicity to the tested water invertebrates as compared to the cv. Strawberry Mint. The impacts of alginite application on all studied antioxidant indexes as well on the acute toxicity of the extracts of both variants of mint were not confirmed.
\end{abstract}

Keywords: mint, alginite, antioxidant, invertebrate, immobilization

\section{Introduction}

The current research is focused on the field of organic farming "bioagriculture" production of feedstuffs, which can contribute essentially to animal and human health and are environmentally friendly. One of the main requirements in the bioagricultural production is the usage of organic fertilizers instead of synthetic substances. Alginite is a complex soil aggregate of algae-based biomass from an organo-mineral origin
(Kúšik et al., 2017; Brindza et al., 2021a, b) with high water absorption capacity (Valla et al., 1980), thus can be used as a natural organic fertilizer. The most effective usage of alginite is attributed to agricultural production as a natural fertilizer (Elečko et al., 1998). Slovakia has in Princiná, Lučenec district, one of the largest alginite deposits in Europe suitable for mining (Kulich et al., 2002).

\footnotetext{
*Corresponding Author: Jarmila Eftimová, University of Veterinary Medicine and Pharmacy in Kosice, Komenskeho 73, 041 81 Kosice, Slovakia

$\triangle$ jarmila.eftimova@uvlf.sk
} 
The plants of the genus Mentha belong to the important representatives of the Lamiaceae family. The genus Mentha consists of eighteen species and eleven hybrids. Several aromatic species of mint contain significant amounts of essential oil thus are economically important (Tucker and Naczi, 2006). The taxonomic and phylogenetic classification of the genus Mentha is very complicated and unclear due to the hyperdiverse of this group of plants (Heylen et al., 2021). Jedrzejczyk and Rewers (2018) summarize the problems with the taxonomic assignment of Mentha species to the following points: a) the existence of variation in basic chromosome number, b) frequent interspecific hybridization, c) cytomixis, d) polymorphism in morphology, e) essential oil composition under different environmental conditions, f) colonial mutant propagation, and g) the occurrence of polyploids, aneuploids, and nothomorphs.

The genus Mentha is characterized by the presence of surface glandular trichomes containing relatively huge amounts of essential oils (Bacílková and Paulusová, 2012). Phenolic acids (rosmarinic and caffeic acids), flavones (luteolin glycoside), and flavanones (eriodictyol glycoside) are probably the main antioxidants in mint (Riachi and De Maria, 2015). The active substances presented in mint are responsible for a broad range of biological activities including digestive, choleretic, carminative, antiseptic, antibacterial, antiviral, antispasmodic, antioxidant, anti-inflammatory, myorelaxant, expectorant, analgesic, tonic, and vasodilatation (McKay and Blumberg, 2006). The plants of the genus Mentha are known for their strong free radical scavenging and antioxidant activities that lead to the decrease of oxidative stress in the biological system (Nickavar et al., 2008). In the Slovak republic, Mentha $\times$ piperita L. is widely used as a medicinal plant, fresh leaves of mint are a popular spice and culinary drug, and are used for the preparation of hot drinks mostly in combination with ginger (Eftimová and Habán, 2012).

The cultivar Strawberry Mint (Mentha $\times$ piperita) is characterized by its shorter stature and small bright green leaves with purple lilac flowers, which have a distinctive sweet aroma that resembles the smell of strawberries. On the other hand, the cultivar Chocolate Mint is a variety of mint that has nuances of chocolate in fragrance and flavour and features rounded to lanceshaped dark green leaves and terminal spikes of small lavender flowers. Both varieties of mint require moist soils that are slightly acidic or neutral in $\mathrm{pH}$ and places with a balanced sun/shade regime.

This experimental work aimed to assess the antioxidant activity, the content of polyphenols and phenolic acids in the extracts of the Mentha $\times$ piperita (cultivars Chocolate Mint and Strawberry Mint) growing in the soil treated by different applications of alginite, as well as to determine the acute toxicity of the water extract of the dried plant samples to daphnids after $48 \mathrm{~h}$ exposure.

\section{Material and methodology}

In the experiment, the plants of the Mentha $\times$ piperita (cultivars Chocolate Mint and Strawberry Mint) were grown on artificially prepared $1 \mathrm{~m}^{2}$ plots, on chernozem soil in the village of Hažín, Michalovce district. At the beginning of the experiment, the soil was planted with the seeds of different variants of mint and treated by various applications of alginite: a) control - the plots without the application of alginite, b) group 1 - the plots were treated with the application of powdered alginite in the dose of $0.1 \mathrm{~kg} / \mathrm{l}$ of water per $1 \mathrm{~m}^{2}$ (in total $1 \mathrm{~kg}$ of alginate), and group 2 - the plots were treated with the application of powdered alginite mixed into the soil at the dose $1 \mathrm{~kg}$ per $1 \mathrm{~m}^{2}$. Except for alginite, the soil was not fertilized and no plant protection products were used. Rainwater from a reservoir was used for watering the plants once a day in the morning. At the end of the experiment, the samples of the plants (only leaves) were dried, cut by a mixer, and stored until analysis.

\section{Total polyphenol content}

The total polyphenol content in the aqueous plant extracts was measured using Folin-Ciocalteu reagent by the spectrophotometric method according to Singleton and Rossi (1965) modified by Suchý et al. (2013). Briefly, $0.1 \mathrm{~mL}$ of each extract was mixed with $0.1 \mathrm{~mL}$ of the Folin-Ciocalteu reagent, $1 \mathrm{~mL}$ of $20 \%$ $(\mathrm{w} / \mathrm{v})$ sodium carbonate, and $8.8 \mathrm{~mL}$ of distilled water. After $30 \mathrm{~min}$. in darkness, the absorbance at $700 \mathrm{~nm}$ was measured using the spectrophotometer Jenway (6405 UV/Vis, England). The total polyphenol content in the aqueous extracts (as caffeic acid equivalent) was calculated from the caffeic acid calibration curve (10-100 $\mu$ g caffeic acid equivalents (CAE) $\left./ L ; R^{2}=0.98\right)$ and is expressed in mg CAE/100g DW.

\section{Antioxidant activity (DPPH radical scavenging assay)}

The radical scavenging activity in the methanol plant extracts of the samples was measured using 2,2-diphenyl-1-picrylhydrazyl (DPPH) (Ahmad et al., 2014). The extracts $(0.5 \mathrm{~mL})$ were mixed with $3.6 \mathrm{~mL}$ of DPPH medium ( $0.025 \mathrm{~g}$ of DPPH in $100 \mathrm{~mL}$ of ethanol). The absorbance of the sample extract was determined 
using the spectrophotometer Jenway (6405 UV/ Vis, England) at $515 \mathrm{~nm}$. Trolox (6-hydroxy-2, 5, 7, 8-tetramethylchroman-2-carboxylic acid) (10-100 mg Trolox/L; $\mathrm{R}^{2}=0.99$ ) was used as the standard for the calibration and the results were expressed in mg Trolox equivalent antioxidant capacity (TEAC)/100g DW.

\section{Total phenolic acid content}

Determination of total phenolic acid content in the ethanol plant extracts was carried out using a method of Farmakopea Polska (1999). Briefly, $0.5 \mathrm{~mL}$ of extract was mixed with $0.5 \mathrm{~mL}$ of $0.5 \mathrm{Mhydrochloric} \mathrm{acid,} 0.5 \mathrm{~mL}$ of Arnova reagent, $0.5 \mathrm{~mL}$ of $1 \mathrm{M}$ sodium hydroxide $(\mathrm{w} / \mathrm{v})$, and $0.5 \mathrm{~mL}$ of distilled water. Absorbance at $490 \mathrm{~nm}$ was measured using the spectrophotometer Jenway (6405 UV/Vis, England). Caffeic acid was used as a standard for the calibration curve $0.01-1.0 \mathrm{mg}$ caffeic acid equivalents (CAE) $\left./ \mathrm{L}, \mathrm{R}^{2}=0.99\right)$ and the results are expressed in mg CAE/100 g DW.

\section{Acute toxicity on Daphnia sp.}

The acute toxicity in the aquatic extracts of dried plant samples of both variants of mint was evaluated by the OECD manual No. 202: Daphnia sp.: Acute immobilisation test (OECD, 2004). The mobility of freshwater invertebrates exposed to the different concentrations of the substance is monitored during a 48-hour ecotoxicological test. Determination of the half-maximal effective concentration $\left(\mathrm{EC}_{50}\right)$ at 24 hours and/or 48 hours is recommended. The experiment was performed with some deviations from the manual, which do not affect the endpoints of the test. Briefly, young forms of daphnids were transferred to each test vessel from inert material. A volume of $10 \mathrm{~mL}$ of tested concentration for 5 daphnids per test vessel was used (20 daphnids per group). The dried samples of mint leaves were diluted in a hot water for $15 \mathrm{~min}$. (the form of decoction) to the concentration of $0.5 \mathrm{mg} / \mathrm{L}$, $1.0 \mathrm{mg} / \mathrm{L}$ and $5.0 \mathrm{mg} / \mathrm{L}$. The control group was only with natural spring water.

\section{Statistical analysis}

All data were analyzed by the one-way analysis of variance (ANOVA) with the Tukey post-hoc test
( $\mathrm{p}<0.05)$. The ecotoxicological results were analyzed by the Probit statistical analysis and the Interpolation statistical method. Association between reported total polyphenols and antioxidant activity were examined by Spearman's correlation.

\section{Results and discussion}

The genus Mentha is a rich source of different biologically active substances, such as essential oils. The main group are monoterpenes with the largest proportion up to $60 \%$ presented by menthol, followed by isomenthone, neomenthyl acetate, and menthone only up to $5 \%$ (Makkar et al., 2018). The amounts of active substances in the plants of peppermint differ widely from variety to variety. The wild mint contains up to $33 \%$ of menthol, up to $29 \%$ of menthone, to $18 \%$ of pulegone, up to $11 \%$ of 1,8 -cineole, and less than $5 \%$ of terpineol- 4 and piperitone (Hajlaoui et al., 2008; Mkaddem et al., 2009).

Flavonoids, gentians, bitter tastants, triterpenes, and tannins are present in the leaves of mint. Sesquiterpenes, such as cadinene and $\beta$-caryophyllene, and other compounds (e.g. isoamyl alcohol, amyl alcohol, hexenol, acetaldehyde, and isovaleraldehyde) are also present in these plants but in small amounts (Bulkova, 2011). Growing evidence indicates that these polyphenols can act as potent natural antioxidants (Kanatt et al., 2007; Rita et al., 2016). The contents of total polyphenols in the aqueous extract of the Mentha $\times$ piperita (cultivars Chocolate Mint and Strawberry Mint) treated by the different applications of alginite are presented in Table 1.

Different laboratory methods for the determination of polyphenols from plants have been applied to study the antioxidant properties in these herbal matrixes. For example, Abootalebian et al. (2016) expressed the amounts of polyphenolic compounds in methanol extracts as tannic acid equivalents (TAE) which ranged from 50.0 to $67.0 \mathrm{mg}$ TAE/g DW. The total phenolic content in M. spicata extract was nearly $26.0 \mathrm{mg}$ of catechin equivalent per g DW as was reported by Kanatt et al. (2007). Scherer et al. (2013) used gallic acid equivalents (GAE) and reported that the methanolic extracts of M. spicata contained around

Table 1 Content of total polyphenols in the samples of mint treated by the different application of alginite

\begin{tabular}{lccc}
\hline Cultivar chocolate mint & mg CAE $/ \mathbf{1 0 0}$ g DW & Cultivar strawberry mint & mg CAE/100 g DW \\
\hline Control & $3.37 \mathrm{ABCDE}$ & Control & 1.23 CFIX \\
Group 1 & $3.08 \mathrm{bIJK}$ & Group 1 & 1.38 EGKM \\
Group 2 & $3.05 \mathrm{aFGH}$ & Group 2 & $1.01 \mathrm{DHJxM}$ \\
\hline
\end{tabular}

Notes: the same letters indicate statistical significance between the two respective groups: $x \mathrm{x}=\mathrm{p}<0.05 ; \mathrm{Xx}=\mathrm{p}<0.01 ; \mathrm{XX}=\mathrm{p}<0.001$ 
$76.0 \mathrm{mg}$ GAE per gram of DW. Benabdallah et al. (2016) analyzed the amounts of total polyphenols in five members of the genus Mentha spp. The authors found that $M$. aquatica, $M$. arvensis, and M. piperita are rich sources of the total polyphenols, while M. pulegium, $M$. rotudifolia, and M. villosa have low total polyphenol contents. The total phenolic content in Medina mint and Hasawi mint was $2.64 \mathrm{mg}$ GAE/g DW and $1.54 \mathrm{mg}$ GAE/g DW, respectively (Brown et al., 2019). Brahmi et al. (2015) compared the phenolic composition in three Algerian Mentha species: M. spicata L., M. pulegium L., and M. rotundifolia L., and the highest content of polyphenols (12.0 mg GAE/g DW) was revealed in M. spicata. On the other hand, the same authors (Brahmi et al., 2014) published the phenolic content in Mentha pulegium to be much higher around $55.0 \mathrm{mg}$ GAE/g DW.

In our experiment, the highest content of total polyphenols ( $3.37 \mathrm{mg} / 100 \mathrm{gDW})$ was determined in the aqueous extract of the $\mathrm{cv}$. Chocolate Mint in the control group. In addition, the amounts of total polyphenols in all samples of the cv. Chocolate Mint were significantly higher as compared to all samples in the cv. Strawberry Mint. We can state that the cv. Chocolate Mint is a richer source of polyphenols (nearly 3 times higher amount) than the cv. Strawberry Mint. On the other hand, we can conclude that the application of alginite did not affect the total polyphenol content in the plants of mint. Nevertheless, the cv. Strawberry Mint treated with the application of alginite mixed into the soil had the lowest amount of total polyphenol, only $1.01 \mathrm{mg}$ CAE/100g DW, but this phenomenon was not revealed in the cv. Chocolate Mint (Table 1).

The usage of peppermint plants in traditional "folk" medicine is attributed to the high amount of biologically active compounds. The polyphenols and lipophilic flavonoids were found to possess a strong antioxidant potential and are the most important pharmaceutically active secondary metabolites in mint (Mimica-Dukic and Bozin, 2008). Growing evidence indicates that the biotic and abiotic factors can influence the composition of biologically active substances in the mint plants thus designating the antioxidant properties in the extracts (Gouvea et al., 2012; Rahimi et al., 2018; Brahmi et al., 2020).

In our study, a Spearman correlation analysis was performed to identify the association of the amount of total polyphenols with the antioxidant activity determined by the DPPH method. The radical scavenging ability (the antioxidant activity determined by the DPPH radical production) was positively correlated with a higher content of total polyphenols in the extract $(r=0.75, * p<0.255)$. These results are in accordance with the previous articles published by Benabdallah et al. (2016). The antioxidant activity was determined by the inhibition \% of DPPH in the ethanol extracts of the cultivars Chocolate Mint and Strawberry Mint (Table 2).

Similarly, the statistical differences in the antioxidant activity between the groups of both variants of mint (Control, Group 1 and Group 2) were not found, but the antioxidant activity in all groups of the cv. Chocolate mint was 2 times higher in comparison to the groups with the cv. Strawberry mint (Table 2). The antioxidant activities in the methanol extracts of the Mentha $\times$ piperita, L. and Mentha spicata, L. were 84.81 and $52.66 \%$, respectively (Martiš and Eftimová, 2019). In this study, around $40 \%$ of antioxidant activity by the DPPH method was found in the cv. Chocolate Mint and

Table 2 Antioxidant activity in the samples of mint treated by the different applications of alginite

\begin{tabular}{lccccc}
\hline $\begin{array}{l}\text { Cultivar chocolate } \\
\text { mint }\end{array}$ & $\begin{array}{c}\text { mg TEAC/100 g } \\
\text { DW }\end{array}$ & $\begin{array}{c}\text { Inhibition \% of } \\
\text { DPPH }\end{array}$ & $\begin{array}{c}\text { Cultivar } \\
\text { strawberry mint }\end{array}$ & $\begin{array}{c}\text { mg TEAC/100 g } \\
\text { DW }\end{array}$ & $\begin{array}{c}\text { Inhibition \% } \\
\text { of DPPH }\end{array}$ \\
\hline Control & $115.7 \mathrm{ABC}$ & $39.2 \%$ & Control & $65.7 \mathrm{ADG}$ & $21.9 \%$ \\
Group 1 & $119.5 \mathrm{DEF}$ & $40.5 \%$ & Group 1 & $48.8 \mathrm{BEH}$ & $16.1 \%$ \\
Group 2 & $117.6 \mathrm{GHI}$ & $39.8 \%$ & Group 2 & $55.7 \mathrm{CFI}$ & $18.5 \%$ \\
\hline
\end{tabular}

Notes: the same letters indicate statistical significance between the two respective groups: $\mathrm{XX}=\mathrm{p}<0.001$

Table 3 Content of phenolic acids in the samples of mint treated by the different applications of alginite

\begin{tabular}{lclc}
\hline Cultivar chocolate mint & mg CAE/100 g DW & Cultivar strawberry mint & mg CAE/100 g DW \\
\hline Control & $1.57 \mathrm{AbC}$ & Control & $1.49 \mathrm{adg}$ \\
Group 1 & $1.57 \mathrm{DeF}$ & Group 1 & $1.51 \mathrm{beh}$ \\
Group 2 & $1.53 \mathrm{GhI}$ & Group 2 & $1.49 \mathrm{cfi}$ \\
\hline
\end{tabular}

Notes: the same letters indicate statistical significance between the two respective groups: $x x=p<0.05 ; X x=p<0.01 ; X X=p<0.001$ 
Agrobiodivers Improv Nutr Health Life Qual, 5, 2021(2): 315-321

Table 4 Effect of water extracts of the Mentha $\times$ piperita L. (cv. Chocolate Mint) on daphnids mobility in the control group

\begin{tabular}{|c|c|c|c|c|}
\hline \multirow[t]{2}{*}{ Parameter } & \multicolumn{4}{|c|}{ Concentration (mg/L) } \\
\hline & 0.0 & 0.5 & 1.0 & 5.0 \\
\hline Affected after 24 h. (\%) & 0 & 20 & 35 & 70 \\
\hline Affected after 48 h. (\%) & 0 & 70 & 90 & 95 \\
\hline \multicolumn{5}{|c|}{ Endpoint (mg per liter) } \\
\hline $\mathrm{EC}_{50}$ after $24 \mathrm{~h} \&$ & \multicolumn{4}{|c|}{2.16 mg/L (CI: $0.97-4.81 \mathrm{mg} / \mathrm{L})$} \\
\hline $\mathrm{EC}_{50}$ after $48 \mathrm{~h} *$ & \multicolumn{4}{|c|}{$0.25 \mathrm{mg} / \mathrm{L}$ (CI: $0.26-2.32 \mathrm{mg} / \mathrm{L})$} \\
\hline
\end{tabular}

Table 5 Effect of water extracts of the Mentha $\times$ piperita L. (cv. Strawberry Mint) on daphnids mobility in the control group

\begin{tabular}{lcccc}
\hline \multirow{2}{*}{ Parameter } & \multicolumn{4}{c}{ Concentration (mg/L) } \\
\cline { 2 - 5 } & $\mathbf{0 . 0}$ & $\mathbf{0 . 5}$ & $\mathbf{1 . 0}$ & $\mathbf{5 . 0}$ \\
\hline Affected after 24 h. (\%) & 0 & 10 & 10 & 35 \\
Affected after 48 h. (\%) & 0 & 15 & 10 & 40 \\
\hline & \multicolumn{4}{c}{ Endpoint (mg per liter) } \\
\hline EC $_{\mathbf{5 0}}$ after 24 h \& & $25.18 \mathrm{mg} / \mathrm{L}(\mathrm{CI}: 5.31-119.52 \mathrm{mg} / \mathrm{L})$ \\
EC $_{\mathbf{5 0}}$ after 48 h \& & \multicolumn{4}{c}{$9.62 \mathrm{mg} / \mathrm{L}(\mathrm{CI}: 3.13-29.57 \mathrm{mg} / \mathrm{L})$} \\
\hline
\end{tabular}

Notes: $\mathrm{CI}$ - confidential interval, \& probit statistical analysis, $\mathrm{EC}_{50}-$ half-maximal effective concentration

lower antioxidant activity of only up to $22 \%$ in the cv. Strawberry Mint.

Hydroxycinnamic and hydroxybenzoic acids are the main groups of phenolic acids in these plants (Tanase et al., 2019). The study performed by Tahira et al. (2011) revealed that the major polyphenolic acids in the genus Mentha are rosmarinic acid, caffeic acid, ferulic acid, and eugenol. The content of phenolic acids in the ethanolic extracts of the cultivars Chocolate Mint and Strawberry Mint is presented in Table 3. All ethanol extracts of the cv. Chocolate Mint, had a higher content of phenolic acids as compared to the ethanol extracts of the cv. Strawberry Mint. No statistical differences in this index were observed between the groups within the same variant of mint.

It is difficult to compare the acute toxicity of mint extracts with the literature because only a very limited number of ecotoxicological studies concerning the acute toxicity of various substances present in the Mentha species were published so far. Recently, Miura et al. (2021) evaluated the toxicological effects of essential oils from different plants, including Mentha arvensis L. and Mentha piperita L. The authors revealed that the half-maximal effective concentration $\left(\mathrm{EC}_{50}\right)$ in daphnids after 48 hours of exposure ( $48 \mathrm{~h}$ ) was $43.7 \mathrm{mg}$ of Mentha piperita essential oil per litre of water medium and Mentha arvensis essential oil was less toxic. On the other hand, the $\mathrm{EC}_{50} 48 \mathrm{~h}$ for menthol, the predominant monoterpene presented in the Mentha species (Eftekhari et al., 2021), is estimated to be $26.6 \mathrm{mg} / \mathrm{L}$ (OECD, 2003).

In our study, only the leaves were used for the preparation of water extracts. Based on our findings, we could presume that the daphnids included in our experiment were affected by different substances (only the amounts of polyphenols and phenolic acids were determined in this study) which are naturally presented in the plant of mint and were extracted into the water extracts during their preparation. Overall, the water extract of the cv. Chocolate Mint was nearly 40 times more toxic to daphnids after $48 \mathrm{~h}$ of exposure than the water extract of the cv. Strawberry Mint (Table 4 and 5). Within the groups of the same variant of mint, the effect of alginate application on the toxicity of water extracts was not revealed. According to the acute toxicity rating scale for aquatic organisms provided by the U.S. Fish and Wildlife Service as published by El-Harbawi (2014), the water extract of the cv. Chocolate Mint is highly toxic, whereas the water extract of the cv. Strawberry Mint belongs to the group of moderately toxic substances.

\section{Conclusion}

Wecanconclude, that the Mentha $\times$ piperita (cv. Chocolate mint) possesses more potent antioxidant properties, due to the higher content of total polyphenols and 
phenolic acids, as compared to the cv. Strawberry Mint. Furthermore, the toxicity of the cv. Chocolate Mint is much higher than the toxicity of the cv. Strawberry Mint. This phenomenon is probably due to a higher amount of some active substances in the cv. Chocolate Mint as was confirmed by the statistically increased amount of all studied biologically active substances as compared to the cv. Strawberry Mint. The beneficial effect of alginite application on all studied parameters has not been demonstrated in this experiment, but the highest content of total polyphenols (3.37 mg/100g DW) was determined in the aqueous extract of the cv. Chocolate Mint in the control group, and the lowest amount of total polyphenol, only $1.01 \mathrm{mg}$ CAE/100 g DW, was found in the water extract of the cv. Strawberry Mint treated with the application of $1 \mathrm{~kg}$ of alginite mixed directly into the soil.

\section{Conflicts of interest}

The authors declare no conflict of interest.

\section{Ethical statement}

This article does not contain any studies that would require an ethical statement.

\section{References}

Abootalebian, M., Keramat, J., Kadivar, M., Ahmadi, F., \& Abdinian, M. (2016). Comparison of total phenolic and antioxidant activity of different Mentha spicata and $M$. longifolia accessions. Annals of Agricultural Sciences, 61, 175-9. https://doi.org/10.1016/j.aoas.2016.10.002

Ahmad, S., Arshad, M.A., Ijaz, S., Khurshid, U., Rashid, F., \& Azam, R. (2014). Review on methods used to determine antioxidant activity. International Journal of Multidisciplinary Research and Development, 1(1), 41-46.

https://www.researchgate.net/publication/313845805

Bacílková, B., Paulusová, H. 2012. In Influence of essential oils and their main active substances on microorganisms and archive material [Vliv silic a jejich hlavních účinných látek na mikroorganismy a na archivní materiál]. National Archive [Národní archiv] [In Czech]. http://www.nacr.cz/Z-files/silice/silice.pdf

Benabdallah, A., Rahmoune, Ch., Boumendjel, M., Aissi, O., \& Messaoud, Ch. (2016). Total phenolic content and antioxidant activity of six wild Mentha species (Lamiaceae) from northeast of Algeria. Asian Pacific Journal of Tropical Biomedicine, 6(9), 760-766.

Brahmi, F., Boulzkbache-Makhlouf, L., Yalaoui-Guellal, D., Chibane, M., \& Madani, K. (2014). Comparative study on the antioxidant effect of aqueous and ethanolic extracts of Mentha pulegium L. grown at two different locations. PhytoChem \&. BioSub Journal, 8, 138-149.

Brahmi, F., Hauchard, D., Guendouze, N., Madani, K., Kiendrebeogo, M., Kamagaju, L., Stévigny, C., Chibane,
M., \& Duez, P. (2015). Phenolic composition, in vitro antioxidant effects and tyrosinase inhibitory activity of three Algerian Mentha species: M. spicata (L.), M. pulegium (L.) and M. rotundifolia (L.) Huds (Lamiaceae). Industrial Crops and Products, 74, 722-730. https://doi.org/10.1016/j.indcrop.2015.04.038

Brahmi, F., Nguyen A.T., Nacoulma, A.P., Sheridan, H., Wang, J., Guendouze, N., Madani, K., \& Duez, P. (2020). Discrimination of Mentha species grown in different geographical areas of Algeria using 1H-NMR-based metabolomics. Journal of Pharmaceutical and Biomedical Analysis, 189, 113430. https://doi.org/10.1016/j.jpba.2020.113430

Brindza, J., Horčinová Sedláčková, V., \& Grygorieva, O. (2021a). Active effects of less known bituminous rock alginate on the biological processes of Solanum lycopersicum L. In Proceeding: Aspecte genetice și fiziologice de creare și dirijare a potenţialului productiv şi adaptiv al plantelor de cultură. Chisinau, Moldova. ISBN 978-9975-56-912-5.

Brindza, J., Vozár, L., Miko, M., Gažo, J., Kovár, P., Horčinová Sedláčková, V., \& Grygorieva, O. (2021b). Unique effects of alginite as a bituminous rock on soil, water, plants and animal organisms. Agrobiodiversity for Improving Nutrition, Health and Life Quality, 5(1), 169-184. https://doi.org/10.15414/ainhlq.2021.0016

Brown, N., John, J.A., \& Shahidi, F. (2019). Polyphenol composition and antioxidant potential of mint leaves. Food production, processing and nutrition, 1(1), 14. https://doi.org/10.1186/s43014-019-0001-8

Eftekhari, A., Khusro, A., Ahmadian, E., Diyaj S.M., Hasanyadeh, A., \& Cucchiarini, M. (2021). Phytochemical and nutra-pharmaceutical attributes of Mentha spp.: A comprehensive review. Arabian Journal of Chemistry, 14(5), 103106. https://doi.org/10.1016/j.arabjc.2021.103106

Eftimová, J., \& Habán, M. (2012). In Production of medicinal plants [Produkcia liečivých rastlín]. Publishing centre and literature shop UVLF [Edičné stredisko a predajňa literatúry UVLF], Košice. ISBN 978-80-8077-314-2 [In Slovak language].

Elečko, M., Konečný, V., \& Vass, D. (1998). Alginite - a new raw material in the non-metallic deposit inventory of Slovakia (maar Pinciná) [Alginit - nová surovina $\mathrm{v}$ nerudnom ložiskovom inventári Slovenska (maar Pinciná)]. Natural gas and diesel oil [Zemný plyn a nafta], 43(2), 325-332 [In Slovak].

El-Harbawi, M. (2014). Toxicity Measurement of Imidazolium Ionic Liquids using Acute Toxicity Test. Procedia Chemistry, 9, 40-52.

Farmakopea Polska V. (1999). In Wyd. P.T. Farm. Warszawa.

Gouvea, Dr., Gobbo-Neto, L., \& Lopes, N.P. (2012). The influence of biotic and abiotic factors on the production of secondary metabolites in medicinal plants. Plant bioactives and drug discovery: principles, practice, and perspectives. John Wiley \& Sons, Inc, Hoboken, NJ. https://doi.org/10.1002/9781118260005.ch12

Hajlaoui, H., Snoussi, M., Jannet H.B., Mighri, Z., \& Bakhrouf, A. (2008). Comparison of chemical composition and 
antimicrobial activities of Mentha longifolia L. ssp. longifolia essential oil from two Tunisian localities (Gabes and Sidi Bouzid). Annals of Microbiology, 58, 513-20. https://doi.org/10.1007/BF03175551

Heylen, O.C.G., Debortoli, N., Marescaux, J., \& Olofsson, J.K. (2021). A Revised Phylogeny of the Mentha spicata Clade Reveals Cryptic Species. Plants, 10(4), 819. https://doi.org/10.3390/plants10040819

https://doi.org/10.1016/B978-0-12-813768-0.00003-7

https://doi.org/10.1016/j.indcrop.2013.07.007

Jedrzejczyk, I., \& Rewers, M. (2018). Genome size and ISSR markers for Mentha L. (Lamiaceae) genetic diversity assessment and species identification. Industrial Crops and Products, 120, 171-179. https://doi.org/10.1016/i.indcrop.2018.04.062

Kanatt, S.R., Chander, R., \& Sharma, A. (2007). Antioxidant potential of mint (Mentha spicata L.) in radiationprocessed lamb meat. Food Chemistry, 100(2), 451-458. https://doi.org/10.1016/j.foodchem.2005.09.066

Kulich, J., Valko, J., \& Obernauer, D. (2002). Perspective of exploitation of alginit in plant nutrition. Journal of Central European Agriculture, 2(3), 200-205.

Kúšik, D., Mižák, J., \& Šoltés, S. (2017). Mineral resources of the Slovak Republic [Nerastné suroviny slovenskej republiky]. State Geological Institute of Dionýz Štúr [Štátny geologický ústav Dionýza Štúra], Bratislava. ISBN 978-80-8174-038-1 [In Slovak].

Makkar, Mk., Sarma, S., \& Kaur, H. (2018). Evaluation of Mentha arvensis essential oil and its major constituents for fungitoxicity. Journal of Food Science and Technology, 55(9), 3840-3844.

https://doi.org/10.1007/s13197-018-3291-y

Martiš, M., \& Eftimová, J. (2019). Influence of intensification factors on the quality of the drug from the genus Mentha L. and the possibility of its contamination [Vplyv intenzifikačných faktorov na kvalitu drogy rodu Mentha L. a možnosti jej kontaminácie]. Folia pharmaceutica cassoviensia, 1(3), 91-97 [In Slovak].

Mckay, D.L., \& Blumberg, J.B. (2006). A review of the bioactivity and potential health benefits of peppermint tea (Mentha piperita L). Phytotherapy Research, 20(8). 619-33. https://doi.org/10.1002/ptr.1936

Mimica-Dukic, N., \& Bozin, B. (2008). Mentha L. species (Lamiaceae) as promising sources of bioactive secondary metabolites. Current Pharmaceutical Design, 14(29), 3141-50.

https://doi.org/10.2174/138161208786404245

Miura, P.T., \& Queiroz, S.C.N. (2021). Study of the chemical composition and ecotoxicological evaluation of essential oils in Daphnia magna with potential use in aquaculture. Aquaculture Research, 52, 3415-3424. https://doi.org/10.1111/are.15186

Mkaddem, M., Bouajila, J., Ennajar, M., Lebrihi, A., Mathieu, F., \& Romdhane, M. (2009). Chemical composition and antimicrobial and antioxidant activities of Mentha (longifolia L. and viridis) essential oils. Journal of Food Science, 74(7), 358-363. https://doi.org/10.1111/j.1750-3841.2009.01272.x
Nickavar, B., Alinaghi, A., \& Kamalinejad, M. (2008). Evaluation of the antioxidant properties of five Mentha species. Iran Juornal of Pharmacetical Research, 7(3), 203-209. https://doi.org/10.22037/IJPR.2010.766

OECD. (2003). In OECD/SIDS Reporton Menthols, Organization for Economic Cooperation and Development, Geneva. http://www.inchem.org/documents/sids/sids/ MENTHOLS.pdf.

OECD. (2004). In Test No. 202: Daphnia sp. Acute Immobilisation Test, OECD iLibrary. https://www.oecdilibrary.org/environment/test-no-202-daphnia-spacute-immobilisation-test 9789264069947-en

Rahimi, Y., Taleei, A., \& Ranjbar, M. (2018). Long-term water deficit modulates antioxidant capacity of peppermint (Mentha piperita L.). Scientia Horticulturae, 237, 36-43. https://doi.org/10.1016/j.scienta.2018.04.004

Riachi, L.G., \& De Maria, C.A. (2015). Peppermint antioxidants revisited. Food Chemistry, 176(1), 72-81. https://doi.org/10.1016/j.foodchem.2014.12.028

Rita, I., Pereira, C., Barros, L., Santos-Buelga, C., \& Ferreira, I.C.F.R. (2016). Mentha spicata L. infusions as sources of antioxidant phenolic compounds: emerging reserve lots with special harvest requirements. Food \& Function Journal, 7(10), 4188-4192. https://doi.org/10.1039/c6fo00841k

Scherer, R., Lemos, M.F., Lemos, M.F., Martinelli, G.C., Martins, J.D.L., \& Da Silva, A.G. (2013). Antioxidant and antibacterial activities and composition of Brazilian spearmint (Mentha spicata L.). Industrial Crops and Products, 50, p. 408-413.

Singleton, V.L., \& Rossi, J.A. (1965). Colorimetry of total phenolics with phosphomolybdic-phosphotungstic acid reagents. American Journal of Enology and Viticulture, 16, 144-158.

Suchý, V., Daňková, I., Dvorská, M., Hrazdilová, E., Kubinová, R., Šmejkal, K., Špačková, V., \& Žemlička, M. (2013). Practical exercises in pharmacognosy [Praktická cvičení $z$ farmakognozie]. University of Veterinary and Pharmaceutical Sciences in Brno [Veterinární a farmaceutická univerzita Brno]. [In Czech].

Tahira, R., Naeemullah, M., Akbar, F., \& Masood, M.S. (2011). Major phenolic acids of local and exotic mint germplasm grown in Islamabad. Pakistan Journal of Botany, 43, 151-154.

Tanase, C., Bujor, O.C., \& Popa, V. (2019). Phenolic and Natural Compounds And Their Influence On Physiological Processes In Plants. Polyphenols in Plants, Watson, R.R., Ed., Academic Press, London, UK. ISBN 978-0-12-813768-0.

Tucker, A.O., \& Naczi, R.F.C. (2006). Mentha: an overview of its classification and relationships. Mint: the genus Mentha. Lawrence B.M. (Ed.), CRC Press, Boca Raton. ISBN 9780429125874.

Valla, M., Kozák, J., \& Drbal, J. (1980). In Exercise of soil science II [Cvičení z pudoznalectví II]. State pedagogical publishing house [Státní pedagogické nakladatelství]. Praha. [In Czech]. 